\title{
Evolutie in de traumachirurgie
}

Citation for published version (APA):

Poeze, M. (2017). Evolutie in de traumachirurgie. Maastricht University. https://doi.org/10.26481/spe.20171110mp

Document status and date:

Published: 10/11/2017

DOI:

10.26481/spe.20171110mp

Document Version:

Publisher's PDF, also known as Version of record

\section{Please check the document version of this publication:}

- A submitted manuscript is the version of the article upon submission and before peer-review. There can be important differences between the submitted version and the official published version of record.

People interested in the research are advised to contact the author for the final version of the publication, or visit the DOI to the publisher's website.

- The final author version and the galley proof are versions of the publication after peer review.

- The final published version features the final layout of the paper including the volume, issue and page numbers.

Link to publication

\footnotetext{
General rights rights.

- You may freely distribute the URL identifying the publication in the public portal. please follow below link for the End User Agreement:

www.umlib.nl/taverne-license

Take down policy

If you believe that this document breaches copyright please contact us at:

repository@maastrichtuniversity.nl

providing details and we will investigate your claim.
}

Copyright and moral rights for the publications made accessible in the public portal are retained by the authors and/or other copyright owners and it is a condition of accessing publications that users recognise and abide by the legal requirements associated with these

- Users may download and print one copy of any publication from the public portal for the purpose of private study or research.

- You may not further distribute the material or use it for any profit-making activity or commercial gain

If the publication is distributed under the terms of Article $25 \mathrm{fa}$ of the Dutch Copyright Act, indicated by the "Taverne" license above, 
®Evolutie in de traumachirurgie 
ISBN: $978-90-5681-472-4$

NUR: 877 Specialistische geneeskunde: chirurgie

All rights reserved. No part of this publication may be reproduced, modified, stored in a retrieval system or made public without the prior written permission of the author or publisher. 


\section{®Evolutie in de traumachirurgie}

\section{Rede}

Uitgesproken bij aanvaarding tot hoogleraar 'Heelkunde in het bijzonder de Traumachirurgie'.

Maastricht, 10-11-2017

Door Prof. dr. M. Poeze 
Geachte (pro)rector, geachte aanwezigen,

Het is vandaag precies 100 jaar geleden dat op 10 november 1917 in de Eerste Wereldoorlog de derde slag om Ieper beëindigd werd. Na ruim drie maanden, 449.000 doden, gewonden en zieken aan de geallieerde kant en 270.000 doden met evenzoveel gewonden aan de Duitse kant verder, was het front slechts acht kilometer verschoven ${ }^{1}$. Het zal nog een jaar en een dag duren, tot 11 november 1918, voor de eerste mondiale oorlog beëindigd wordt. Hoewel het aantal personeelsleden van de medische dienst, gezien de onvoorstelbare aantallen gewonde patiënten, enorm groeide, stond men machteloos tegenover deze aantallen en typen verwondingen, veroorzaakt door de helaas steeds effectiever wordende wapens om ernstige weefselschade te veroorzaken. Als de directe kans op overlijden niet werd meegeteld, had de gewonde Brit of Duitser een kans van een op zes à zeven en een Fransman zelfs van een op vier om ten gevolge van zijn verdere verwondingen te overlijden ${ }^{2}$. Het was niet dat er geen vooruitgang geboekt werd in de zorg aan deze patiënten. Volgens veel van de toen werkzame chirurgen was de oorlog zelfs 'goed voor de geneeskunde', door de mogelijkheden revolutionair nieuwe behandelingen uit te vinden en te testen. In de historische literatuur wordt echter een discussie ${ }^{2}$ gevoerd of de vooruitgang in de traumachirurgie, zoals toen 'avant la lettre' uitgevoerd, volgens een revolutie of een evolutie vooruitging. Waren het revolutionaire nieuwe uitvindingen die de traumazorg met sprongen vooruitbracht, of was er daarentegen sprake van meer geleidelijke verbeteringen, een evolutie, van eerdere uitvindingen die een impact op de zorg hadden, gezien de schaalgrootte waarin ze werden toegepast?

Eén van de vele uitdagingen voor de behandelend artsen, was hoe de veelal open botbreuken, in medische termen fracturen genaamd, te behandelen, die door granaatscherven of de nieuwe hoog kaliber machinegeweren werden veroorzaakt. Dr. George MacLeod (1828-1892), een

\footnotetext{
${ }^{1}$ Halfweg Menin Road en Ypernstrasse: Gheluvelt 1914 - 1918; Volume 3 van Studies, Association for Battlefield Archaeology in Flanders. Jan Vancoillie. Association for Battlefield Archaeology in Flanders, 2002

${ }^{2}$ Before My Helpless Sight. Suffering, Dying and Military Medicine on the Western Front, 1914-1918. Leo van Bergen. Routhledge Taylor \& Francis Group, 2009.
} 
chirurg in een algemeen ziekenhuis in Sebastopol (Oekraïne) ten tijde van de Krimoorlog schreef hierover in zijn dagboek:

'Van alle ernstige letsels die in de oorlog beschreven zijn, zijn de open en meervoudige fracturen het meest voorkomend en hebben de meest ernstige gevolgen.... In de Krimoorlog waren deze letsels opvallend en buitengewoon dodelijk in de afloop.... Er kan geen twijfel bestaan dat het beleid, die alle chirurgen van ons leger beïnvloedde, deze letsels conservatief te behandelen een belangrijke oorzaak was van die sterfte' ${ }^{3}$.

Zo had het overlijdensrisico van een soldaat met een bovenbeensbreuk een onwaarschijnlijk hoog overlijdensrisico van tachtig procent. Door het stabiel maken van het been met gips kon dit omlaag gebracht worden naar twintig procent ${ }^{4}$. Alhoewel deze vooruitgang in de overleving revolutionair klinkt, was het stabiliseren van een gebroken ledemaat met gips al in 1812 beschreven door Dominique Jean Larrey (1768-1842), een chirurg uit het leger van Napoleon ${ }^{5}$. De techniek van het gipsen van het been of arm met een breuk werd echter vóór de Eerste Wereldoorlog nog niet eerder op een dergelijke schaal toegepast, waardoor de winst van deze behandeling voorheen minder zichtbaar was.

Een dergelijk principe gold uiteraard ook voor andere belangrijke thema's, zoals de evacuatie en organisatie van gewondenopvang, wondbehandeling, chirurgische technieken en technologie (met name gericht op amputatie), infectiebestrijding met bijvoorbeeld antibiotica en tot slot bloedtransfusie. Deze vooruitgang op deze gebieden in de militaire chirurgische behandeling heeft natuurlijk een significante impact gehad op de civiele behandeling van ongevalsslachtoffers. Ik zal hier verder met name de fractuurgenezing bespreken, als voorbeeld om de revoluties en evoluties in de traumachirurgie toe te lichten en te begrijpen hoe we deze in de nabije toekomst vervolg kunnen geven.

\footnotetext{
${ }^{3}$ Macleod GHB. Notes on the surgery of the war in the crimea, with remarks on the treatment of gunshot wounds. London, England: John Churchill; 1858.

${ }^{4}$ Arthur Rocyn Jones, F.R.C.S., London. "JONES, Sir ROBERT, Bart.". Welsh Biography Online. Retrieved 31 December 2010.

${ }^{5}$ Mémoires de chirurgie militaire, et campagnes de D. J. Larrey. Larrey, D. J. (Dominique Jean), baron, 1766-1842, Paris, J. Smith, 1812.
} 
In de komende drie kwartier zal ik u meenemen in de recente en huidige uitdagingen van een patiënt met een fractuur om tot een goede genezing te komen. De boodschap die ik u hier wil overdragen, is dat het onderzoek in de traumachirurgie van een biomechanische naar een metabole benadering van fractuurgenezing moet komen. Dit vereist een nieuwe invulling van het onderzoek op het gebied van de ontstaanswijze, behandeling en de evaluatie van deze behandeling in de traumachirurgie vereist. Of dat via revolutie of evolutie zal gaan, dus of via een plotselinge verandering of via een geleidelijke ontwikkeling, zal hopelijk in de komende drie kwartier duidelijk worden.

Ik sta hier voor u als hoogleraar traumachirurgie vanuit mijn leeropdracht onderzoek, maar dit kan men natuurlijk niet los zien van de andere twee academische pijlers, namelijk zorg en onderwijs, om een aantal ontwikkelingen in de traumachirurgie te beschrijven. Ik zal $u$ eerst beschrijven welke ontwikkelingen ingezet zijn in de zorg en het onderwijs, voordat ik de onderzoekslijn die ik heb opgezet en de plannen voor de komende jaren uit zal leggen.

De traumachirurgie is de studie van verwondingen, die door ongevallen of geweld zijn veroorzaakt, inclusief de chirurgische behandeling. Traumachirurgie is een van de oudste aandachtsgebieden binnen de zorg, maar de beweging naar een zelfstandig vakgebied is er pas een van de recente geschiedenis. Tevens verstaat men niet overal hetzelfde onder de benaming ervan. In tegenstelling tot elders in de wereld wordt er in Nederland in het vak traumachirurgie geen onderscheid gemaakt tussen de Angelsaksische termen "orthopedic trauma surgery" (betreffende botbreuken en extremiteitsletsels) en "trauma surgery" (overige letsels, zoals schot- en steekverwondingen van buik en borstholte). Daardoor worden patiënten met botbreuken in Nederland voor 75 procent door traumachirurgen behandeld (de overige 25 procent wordt behandeld door orthopeden). Ook worden bij de meervoudig gewonde patiënt de acute operaties van de borstholte, buikholte en de weke delen letsels door de traumachirurgen uitgevoerd. Daarmee wordt de patiënt met een trauma in Nederland door de traumachirurg met een meer holistische kijk benaderd en is de zorg minder versnipperd. Het gaat 
niet immers niet alleen om welke botbreuk de patiënt heeft, maar met name om welke patiënt de botbreuk heeft.

De traumachirurg heeft de afgelopen decennia deze expertise in de acute behandeling van fracturen ook uitgebreid naar de vervolgingrepen, zoals onder andere de behandeling van de niet genezende fractuur of non-union, waar ik later op terug zal komen. $\mathrm{Er}$ is in de dagelijkse praktijk dan ook een verschuiving in de werkzaamheden van de traumachirurg opgetreden, van een groot deel algemeen chirurgische taken, denk aan de verwijdering van een ontstoken blindedarm, met een beetje trauma erbij, naar een volledige invulling met traumazorg. Ons vak vraagt zoveel specifieke expertise, dat je dat er niet meer even naast doet. De traumachirurgie is een volwassen en zelfstandig vakgebied geworden dat alle aspecten van de traumazorg, zowel weke delen als extremiteitsletsels, behandelt maar wel beperkt tot die afwijkingen die na een ongeval optreden. Hierin ligt onze expertise en kracht.

Deze realisatie is belangrijk, omdat de zojuist genoemde verschuiving nog niet ten einde is en we nu de kans hebben het vakgebied de juiste kant op te sturen. We zijn aangekomen op het punt een keuze te moeten maken waar de focus van de traumachirurgie komt te liggen: de fractuurzorg versus de behandeling van buik en borstkasletsels. In mijn visie zal dit de eerste zal betreffen. Hieruit volgt ook dat we de komende jaren niet de kant van de 'acute care surgery' op moeten gaan, welke in Amerika gepromoot wordt door de traumachirurgen, om zich niet alleen bezig te houden met de opvang en behandeling van traumapatiënten (in Amerika dus exclusief de extremiteitsletsels), maar ook de behandeling van een algemeen zieke patiëntenpopulatie met een chirurgische problematiek, van bijvoorbeeld een blindedarmontsteking tot de traumatische buik en borstkasletsels. De extremiteitsletsels/fracturen blijven daar vooralsnog bij de "orthopedic trauma surgeon" zoals eerder beschreven.

Waar de eerste hoogleraar voor alleen de Traumatologie in Maastricht, Jouwert Stapert, in zijn inauguratie ${ }^{6}$ nog pleitte voor een stevige verankering binnen het moederspecialisme Chirurgie, pleitte zijn opvolger Peter Brink er in zijn rede al

${ }^{6}$ Doen wat nodig is! (De tijd van nadenken is voorbij). Jouwert Stapert, Maastricht Universitary Library, 1995. 
voor om de ontwikkeling in gang te zetten naar een federatief bestel binnen de Chirurgie?

Om bovenstaande en de ontwikkelingen van de afgelopen jaren samen te vatten, de evolutie die zich heeft afgespeeld met betrekking tot de verhouding van traumachirurgie met de algemene chirurgie brengt nu de noodzaak tot revolutie met zich mee. Gegeven de huidige inhoud van de Traumachirurgie is het leggen van verbindingen met de afdeling Orthopedie daarom een logischer ontwikkeling voor de toekomst. Het vakgebied Orthopedie heeft immers vele raakvlakken de Traumachirurgie, zoals de behandeling van gewrichtsslijtage of artrose, die vervroegd kan optreden door een fractuur. Hier heeft de orthopedie zich in Maastricht met name gespecialiseerd in de behandeling van vroege artrose. In Maastricht hebben we een aantal jaar geleden een samenwerking opgezet, waarbij de vakgroep Orthopedie en de traumasectie nu in een gezamenlijke functionele eenheid de expertise inbrengen om de traumapatiënt te behandelen. Dit is in de Nederlandse academische centra een unieke insteek en biedt kansen om gezamenlijk zorg te verlenen, gezamenlijk onderwijs aan te bieden en gezamenlijk het onderzoek verder uit te bouwen. Dit is alleen mogelijk doordat mijn collegae van de Orthopedie en Traumachirurgie over de eigen schaduw heen zijn gestapt en niet naar de verschillen in cultuur, maar naar een gezamenlijke visie zijn gaan kijken. Het is fantastisch te zien welk een inzet iedereen toont en daar wil ik alle betrokkenen dan ook een enorm compliment voor geven. De komende jaren werken we gezamenlijk aan het verder vormgeven van deze samenwerking richting een zelfstandige afdeling traumachirurgie. In deze organisatiestructuur zullen traumachirurgen en orthopeden met speciale interesse in de traumazorg samen de opvang en behandeling bemensen.

Naast deze lokale vernieuwingen is de traumazorg ook op landelijk en regionaal niveau aan diverse veranderingen onderhevig. In Nederland is, naar analogie van Amerika, een trauma-opvang systeem gecreëerd binnen 11 traumaregio's, waar de traumazorg geleverd wordt door de 11 traumacentra en de daarmee samenwerkende regionale ziekenhuizen. Het ontstaan van dit systeem kan beschouwd

\footnotetext{
${ }^{7}$ Traumatologie de deur uit. Peter Rinze Gérard Brink, Maastricht University Library, 2004.
} 
worden als een revolutie: na het verschijnen in 1994 van het rapport 'De keten rammelt' is een regionale professionalisering van de traumazorg ingezet ${ }^{8}$. Het Landelijke Netwerk Acute Zorg, het LNAZ, werkt hierin samen met de regionale ketenpartners. Het LNAZ faciliteert en coördineert de acute zorg in Nederland. Deze voorheen afwezige structuur heeft ertoe geleid dat er een beter inzicht in de zorg gekomen is en deze ook meer standaard geworden is. In onze regio verzorgt het Netwerk Acute Zorg Limburg deze functie in Limburg. De afgelopen twee jaar heb ik het voorrecht gehad het medisch hoofd van deze groep te zijn. Ik denk niet dat ik snel een zo gedreven groep tegen zal komen, die de mensen in de acute zorg wil ondersteunen om gezamenlijk de kwaliteit van zorg te verbeteren. Met deze gezamenlijke inspanning bewerkstelligen we een evolutie tot een volwassen trauma systeem: recente initiatieven tot verdere regionalisatie en concentratie moeten leiden tot een verdere daling in het sterfterisico. Het Zorginstituut Nederland heeft in haar recente rapport 'Spoed moet goed' ${ }^{9}$ voor de eerste keer normen gesteld aan de traumacentra voor de hoeveelheid en de mate van concentratie van eerste opvang van de meest ernstige traumapatiënten, naar analogie van de normering, zoals ze in Amerika en Groot-Brittannië is ingevoerd. Alhoewel deze ontwikkeling ingezet is met een kwaliteitsoogmerk, bemerk ik dat sommigen de neiging de inhoud van de ontwikkeling ook op andere dan inhoudelijke argumenten te sturen. De discussie die gevoerd wordt om te streven naar een reductie van het aantal traumacentra, zonder naar inpasbaarheid in de huidige gezondheidszorg te kijken, is ingegeven door exclusie en niet inclusie. Vooralsnog lijkt mij dan ook het beleid van het Landelijk Netwerk Acute Zorg, om door regionale concentratie van de zorg voor de multitraumapatiënt de verwachte verhoging van kwaliteit van zorg te bewerkstelligen dan ook de juiste. In onze regio betekent het uitrollen van initiatieven voor een betere triage op straat met verdere concentratie van patiënten met multipele trauma's naar het traumacentrum. Kortom, ervoor

\footnotetext{
${ }^{8}$ De keten rammelt. Onderzoek naar de afstemming binnen de spoedeisende hulpverlening" Uitgave van de Geneeskundige Inspectie van de Volksgezondheid, 1994.

${ }^{9}$ Spoed moet goed: indicatoren en normen voor zes spoedzorgindicaties.

Zorginstituut Nederland, 2015
} 
zorgen dat de complexe traumapatiënt zonder omwegen naar het juiste ziekenhuis wordt gebracht. Hierbij zal de opvang aldaar worden uitgevoerd door traumachirurgen uit de regio die affiniteit hebben met de multitraumazorg. In dit geval volgt de patiënt, waarvoor de tijd dringt, de setting waarbij alle faciliteiten aanwezig zijn voor complexe zorg. Daarnaast zullen we expertteams vormen voor de behandeling van complexe fracturen, waarbij de operaties op alle locaties in de regio uitgevoerd kunnen worden en de patiënt niet de setting maar de chirurg volgt. Door bij deze teams te bouwen op de participatie van traumachirurgen uit alle regionale ziekenhuizen, blijft iedereen betrokken ondanks de eerdergenoemde benodigde verdere concentratie van de traumazorg. Deze actieve betrokkenheid is een organisatiemodel van inclusie, dat rekening houdt met elkaars expertise, de krapte op de arbeidsmarkt, de gestelde normen en de kwaliteitscriteria. Dit is geen eenvoudig lopend traject, maar ik zie met vertrouwen de samenwerking in de regio in deze transitie tegemoet en bedank alvast de raad van bestuur en onze ketenpartners voor het getoonde lef om dit in de regio op te pakken.

De veranderingen in de inhoud van het vak hebben ook consequenties voor de opleiding tot Traumachirurg. Dit is nu nog een opleiding binnen de Chirurgie, gericht op de chirurgische behandeling van een divers scala aan aandoeningen, dat men vroeger onder de 'Algemene Chirurgie' liet vallen. Door de gestaag toegenomen specialisatie en normering bestaat de 'Algemene Chirurgie' echter niet meer. De komende jaren zal de opleiding tot Traumachirurg ook meer recht moeten doen aan deze evolutie en zou naar mijn mening tot een zelfstandige opleiding omgevormd moeten worden. Dit zal een ware revolutie in de inhoud van onze opleiding betekenen. Ik zie deze nieuwe vorm als volgt voor me: in de eerste twee jaar wordt er een gezamenlijke vooropleiding gegeven, zoals nu al voor alle chirurgische disciplines geldt. Hierin zal aandacht zijn voor weke delen behandeling, maar ook de intensive care zorg. Vervolgens volgt de traumachirurg in opleiding gedurende twee jaar een gedeelde opleiding tot Traumachirurg en Orthopeed, naar analogie van Duitsland, inclusief natuurlijk daarin zowel een stage in acute behandeling van abdominale en thoracale problemen als ook de aandoeningen van de extremiteiten. Hierna volgen nog 
een of twee jaar, waarin de traumachirurg in opleiding de differentiatie voltooid en klaargestoomd wordt in alle aspecten van de traumachirurgie. Tenslotte zal er veelal nog een vervolgopleiding, fellowship genaamd, gevolgd worden, afhankelijk van de geplande vervolgcarrière. Een deel van de toekomstige traumachirurgen zullen dat in een van de traumacentra gaan doen en daarmee zal hun opleiding ook meer gericht moeten zijn op de acute behandeling van abdominale en thoracale letsels, naast de extremiteitsletsels. Een ander deel zal niet werkzaam gaan zijn in een dergelijk centrum en daarmee zal het fellowship zich meer kunnen richten op de zorg voor de patiënt met extremiteitsletsel en fracturen.

Niet alleen in de opleiding tot specialist zal aandacht besteed moeten worden aan de zorg voor patiënten met een acuut letsel. De trauma wereld is pionier geweest met het aanbieden van een gestructureerde opleiding in de traumazorg via de Advanced Trauma Life Support ${ }^{10}$. Het voordeel van een dergelijke methodiek is dat de patiënt snel en adequaat beoordeeld en behandeld wordt en dat alle hulpverleners in dezelfde methodiek werken. Deze methodiek is in het onderwijs ook naar de pre-hospitale fase vertaald, voor bijvoorbeeld medewerkers van de ambulancediensten, en naar andere vormen van opvang van acuut zieke patiënten. Deze bouwstenen hebben voor een stevig fundament gezorgd in de medische vervolgopleiding, maar zouden eigenlijk ook al vanaf het eerste moment meegenomen moeten worden in de opleiding tot arts. $\mathrm{Nu}$ is het aanbod van het onderwijs over acute zorg voor studenten in Maastricht nog versnipperd en niet duidelijk herkenbaar. Inmiddels zijn we met een groep bestaande uit clinici en onderwijskundigen bezig een programma te vormen, dat tot doel heeft aankomende artsen op te leiden die zich bewust zijn van de acute zorgbehoefte van een patiënt en die zich voldoende competent voelen om die zorg praktisch te kunnen leveren. Anders dan in het huidige aanbod zal het studiepad "acute zorg" duidelijk herkenbaar moeten zijn voor studenten en meer praktisch van aard. Bovendien moet het een longitudinaal

\footnotetext{
${ }^{10}$ Carmont MR The Advanced Trauma Life Support course: a history of its development and review of related literature Postgraduate Medical Journal 2005; 81:87-91.
} 
karakter krijgen, met het herhalen en opbouwen in moeilijkheid van de studiestof, waarbij de manier van toetsen het verdere leren stimuleert.

Dit gezegd hebbende over de ontwikkeling in de traumazorg en opleiding, wil ik u uitleggen welke richting onze onderzoeksgroep heeft ingeslagen. Hiervoor moet ik terugkomen op de behandeling van die gewonde soldaat met een gebroken bovenbeen en hoe zijn behandeling zich in de loop van anderhalve eeuw heeft ontwikkeld. Dit zal ook duidelijk maken hoe de behandeling van een traumapatiënt met een fractuur in de civiele wereld is veranderd en dat de focus van ons onderzoek ook in die lijn zal moeten meegaan. Om dit duidelijk te maken moeten we ons eerst afvragen, waaraan de soldaat met een ernstig letsel en een fractuur in 1855 doodging. Door de ten tijde van de Krimoorlog nog heersende veronderstelling dat dergelijke fracturen ongemoeid gelaten moesten worden, bleven de gebroken botdelen bewegen en zo het wondgebied beschadigen, waardoor grote bloedingen ontstonden. Zestig procent overleefde een dergelijke bloeding niet. Door een stabiliserende gipsspalk zoals in de Eerste Wereldoorlog gepropageerd door de Britse chirurg Robert Jones (18571933 $)^{11}$, traden deze catastrofale verbloedingen minder vaak op, maar diende zich voor de patiënt het volgende probleem aan: wondinfecties. Doordat men beschadigd weefsel rondom de wond niet verwijderde, ontstonden ernstige infecties, waarbij de amputatie van het ledemaat meestal de enige oplossing was. Het uitgebreid schoonmaken van de wond met verwijderen van dood of afstervend weefsel, zoals ingevoerd in de Tweede Wereldoorlog, kon de noodzaak tot amputatie significant verlagen: van twaalf naar 1,7 procent ${ }^{12}$. Ook de stabilisatie van de fracturen zelf verbeterde aanzienlijk door toepassing van de onder andere de externe fixateur (dat is een uitwendig frame). Ook werden door de Duitser Gerhard Küntschner ${ }^{13}$ beschreven toepassing van pennen in de mergholte van de

\footnotetext{
${ }^{11}$ Arthur Rocyn Jones, F.R.C.S., London. "JONES, Sir ROBERT, Bart.". Welsh Biography Online. Retrieved 31 December 2010.

12 Treatment of War Wounds: A Historical Review. Manring MM, Hawk A, Calhoun JH, Andersen RC. Clinical Orthopaedics and Related Research. 2009;467(8):2168-2191.

${ }_{13}$ Die Marknalung von Knochenbruchen. Küntscher G. Langenbecks. Arch Klin Chir 1940; 200:443-55.
} 
pijpbeenderen of door een fixatie met metalen plaat en schroeven, zoals voor het eerst door de Belg Robert Danis ${ }^{14}$ beschreven, de technieken van de stabilisatie van fracturen verbeterd. $\mathrm{Na}$ de Tweede Wereldoorlog was de kans op sterfte aan de directe gevolgen van fracturen, in de vorm van verbloeding en infectie minder, maar diende zich weer een nieuw probleem aan; in de Koreaanse Oorlog bleken deze soldaten, die eerder aan verbloeding zouden overlijden, een ernstige algehele, of systemische, reactie van het lichaam te vertonen, waardoor organen minder goed gingen functioneren. Soldaten bleken een acuut falen van de nierfunctie te ontwikkelen, onder andere door een te veel aan toegediende vloeistoffen. In negentig procent van de gevallen was deze stoornis fataal. Door het geven van bloedtransfusies verlaagde de kans op nierfalen en door de introductie van dialyse in $1952^{15}$ daalde het risico nog verder. Het gevaar dat een patiënt vervolgens oedeem, vocht, in de longen ontwikkelde zorgde voor de volgende uitdaging, wat een vooruitgang in de beademingsmogelijkheden teweegbracht. Deze historie laat zien dat men in cycli van probleem via inzicht naar oplossing stapsgewijs de traumazorg verbeterde en uiteindelijk het risico van de gewonde soldaat op overlijden aan de algehele gevolgen van een letsel aanzienlijk gedaald is. Ook illustreert het dat het initiële letsel maar een deel van het probleem is; oog hebben voor de systemische gevolgen van een verwonding en bijbehorende behandeling is essentieel voor een goede traumachirurg.

De lessen getrokken tegen de achtergrond van dit oorlogsgeweld hebben ook gezorgd voor een verbeterde traumazorg in de civiele wereld, los van alle preventieve maar niet minder belangrijke maatregelen zoals autogordels en airbags. Vandaag de dag leert onze eigen nationale traumaregistratie dat het risico op overlijden in de eerste fase na een ernstig trauma in het verkeer gedaald is tot vijf procent ${ }^{16}$. Zo stierven in Nederland in 1970 nog 3300 mensen in het verkeer, 1300 in 1995 en 570, in 2014, terwijl de verkeersintensiteit in dezelfde periode met een

\footnotetext{
${ }^{14}$ La technique de l'ostéosynthèse Masson et Cie, Etude de quelques procédés. Danis R. Paris, 1932.

${ }^{15}$ Teschan PE 1955. Haemodialysis in military casualties. ASAIO Journal $1: 52-4$

${ }^{16}$ Rapport 'Traumazorg in beeld'. LandelijkeTraumaregistratie 2011 - 2015.
} 
factor 2,5 toenam ${ }^{17}$. De algemene (lees systemische) gevolgen, zoals bijvoorbeeld verbloeding, van een trauma kunnen steeds effectiever behandeld worden. Deze recente data komen uit de nationale traumaregistratie, een gezamenlijk en landelijk gedragen initiatief is. Dat de landelijke samenwerking van traumaregio's zoals eerder beschreven vruchten afwerpt, mag blijken uit het feit dat de uitkomsten van behandeling in Nederland niet onderdoen voor die in de Verenigde Staten, van oudsher de referentie vanwege hun goed georganiseerde traumazorg.

Ondanks de reductie in het sterfterisico van de ernstig gewonde traumapatiënt, neemt het aantal ernstig gewonde trauma patiënten wel toe. Zo waren er in het jaar 2000, 15.000 ernstige verkeersgewonden, terwijl in 2015 dit er al 21.300 waren ${ }^{17}$. In totaal zijn verwondingen verantwoordelijk voor 8,3 procent van de totale ziektelast in Nederland, zoals deze berekend is voor de zestig belangrijkste ziekten en aandoeningen. Dit is in dezelfde orde van grootte als de ziektelast voor patiënten met diabetes, chronische longziekten en ziekten van het bewegingsapparaat. Letsels kosten de samenleving ten minste 3,6 miljard euro per jaar, waarvan de kosten van verkeersongevallen alleen al 680 miljoen euro bedragen ${ }^{17}$. Het belang van onderzoek naar en beperken van de lange termijn fysieke en psychische gevolgen van een ongeval kan dan ook niet genoeg onderstreept worden. Dit onderzoek naar de lange termijneffecten zal naar mijn verwachting een steeds belangrijker stempel op ons beleid en onderzoek gaan drukken.

Een van de uitdagende klinische problemen waar we als traumachirurgen tegenaan lopen is het niet genezen van een fractuur, de zogenaamde non-union. Het totale aantal personen dat in Nederland jaarlijks een fractuur oploopt is $110.000^{18}$ (waaronder bijvoorbeeld 20.000 heupfracturen per jaar). Als we het totaal aan fracturen samennemen, is het risico op een non-union rond de vijf procent ${ }^{19}$. Dit risico kan overigens oplopen tot 46 procent in hoog-risicogroepen, zoals patiënten met een open fractuur van het onderbeen.

\footnotetext{
${ }^{17}$ Verkeersdoden in Nederland. SWOV-Factsheet, mei 2017. SWOV, Den Haag.

${ }_{18}$ Letsels 2016. Kerncijfers LIS. Rapport: 675. VeiligheidNL, september 2017.

19 Epidemiology of Fracture Nonunion in 18 Human Bones. Zura R, Xiong Z, Einhorn T, Watson JT, Ostrum RF, Prayson MJ, Della rocca GJ, Mehta S, McKinley T, Wang Z, Steen RG. JAMA Surg. 2016;151(11): e162775.
} 
Dat betekent dat er in totaal per jaar tussen de 5000 en 6000 patiënten in Nederland zijn met een niet-goed genezende fractuur. Het hebben van een non-union heeft een belangrijke invloed op de kwaliteit van leven, waarbij deze zelfs vijf jaar na een succesvolle behandeling van de non-union verlaagd is ten opzichte van de algemene bevolking. De kwaliteit van leven is vergelijkbaar met of zelfs lager dan die van patiënten met bijvoorbeeld diabetes of een herseninfarct ${ }^{20}$. Eén van de vragen die daarbij opkomt is dan ook of we wel van een 'succesvolle' behandeling mogen spreken.

Om te begrijpen hoe wij dit probleem benaderen zal ik allereerst de normale fractuurgenezing beschrijven, klassiek ingedeeld in vier elkaar overlappende en opeenvolgende fasen op. Wanneer een bot breekt, scheuren er bloedvaten in het bot, het botvlies (periost in medische termen), en ook in het omliggende weefsel. Hierdoor ontstaat een bloeduitstorting, in medische termen fractuurhematoom genaamd. In dit hematoom ontstaat een steriele ontstekingsreactie, die de eerste herstelreactie vormt en van waaruit een beginnend littekenweefsel gevormd wordt. Vanuit dit weefsel groeien grillige kraakbeenstructuren, voornamelijk van onder het periost van beide fractuurdelen uit, en daarna onregelmatige botbalkjes, vanuit het merg, om de breuk te overbruggen. Dit zogenaamde callusweefsel begint na twee tot drie weken te verharden. Uiteindelijk wordt dit callusweefsel omgezet in botweefsel tijdens een remodellerings- of omvormingsfase.

Een stoornis in een van deze fasen kan leiden tot een vertraging in de fractuurgenezing of tot een onomkeerbare stop in het herstel, de zogenaamde non-union.

Eenvoudig ingedeeld zijn er twee vormen van non-union te onderscheiden: de ene vorm wordt atrofische non-union genoemd, de andere vorm wordt hypertrofische non-union genoemd. Klassiek gezien leerden we dat de eerste variant een duidelijke metabole achtergrond en de tweede vorm een biomechanische achtergrond heeft. Met metabolisme bedoelen we het geheel van biochemische processen van omzetting van voedsel in de cellen van ons lichaam, ook wel stofwisseling genoemd. Met biomechanisch bedoelen we dat

\footnotetext{
${ }^{20}$ Time Trade-Off as a Measure of Health-Related Quality of Life: Long Bone Nonunions Have a Devastating Impact. Schottel PC, O'Connor DP, Brinker MR. J Bone Joint Surg Am 2015;97(17):1406-10.
} 
de fractuurdelen niet stabiel tegen elkaar aanzitten; denk weer aan de soldaat met gebroken been waar men vroeger geen spalk voor aanbracht. In eigen onderzoek hebben we echter aangetoond dat in beide vormen van non-union, dus niet alleen in de atrofische maar ook in de hypertrofische, de stofwisseling duidelijk verstoord is. De hypertrofische variant kunnen we vaak wel met biomechanische opties behandelen, door het toevoegen van stabiliteit aan de fractuur door het aanbrengen van extra platen of het plaatsen van een mergpen met een grotere diameter. Echter, ons begrip en daarmee onze mogelijkheden om de stofwisseling te verbeteren zijn nog beperkt. De huidige technieken om de afwijkingen in de stofwisseling van de fractuurgenezing te behandelen zijn ofwel het bijplaatsen van bot weggehaald van een niet-aangedane plaats bij de patiënt of het vervangen van bot door kunstmatige middelen met of zonder het toevoegen van groeifactoren. Om een succesvolle genezing te krijgen, moeten deze laatste twee lokale interventies twee dingen bieden: ten eerste een structuur, waarlangs het eigen bot kan uitgroeien, de zgn. osteoconductieve eigenschap, ofwel een botgeleider zijn. Ten tweede moet er een stimulans zijn voor het botweefsel om tot uitgroei over te gaan, de zgn. osteoinductieve eigenschap. Er zijn weinig producten die zowel deze osteoconductieve als osteoinductieve eigenschappen hebben, laat staan dat we volledig begrijpen hoe deze factoren precies werken. Op dit moment is daarom nog steeds de gouden standaard het gebruik van het bot van de patiënt zelf. Uit diverse studies weten we echter dat de kwaliteit van dit bot vaak niet goed genoeg is en het oogsten, zoals we dat noemen, geeft veelvuldig complicaties. Het succespercentage van de behandeling van een non-union varieert tussen de 75 en 85 procent. Dit magere percentage komt met name op het conto van de groep met een atrofische non-union, aangezien van deze groep slechts zestig procent na een operatie succesvolle vastgroei van de non-union heeft. Deze patiënten hebben dan ook vaak meerdere operaties nodig voordat de nonunion vastgroeit. In onze patiëntengroep met een atrofische non-union blijkt dat er gemiddeld bijna vijf keer geopereerd moet worden om succes te krijgen. De kennis over welke processen deze behandeling tot een succes of falen maken, is echter bijzonder beperkt. 
Vanuit de internationale literatuur is door chirurgonderzoekers Giannoudis en Schmidmaier een concept bedacht om de behandeling van non-union te structureren: het pentagoon concept ${ }^{21}$. Hier beschrijft men vijf hoekstenen voor de behandeling van non-union: lokale mechanische stabiliteit, voldoende en actieve botcellen ter plaatse van de non-union, aanwezigheid van groeifactoren, een goede geleidingsstructuur (de zogenaamde 'scaffold') en ten slotte een adequate lokale bloedvoorziening.

Ik stel voor dat we een extra element aan deze factoren toevoegen en de pentagoon vervangen door een hexagoon, door het toevoegen van de systemische afwijkingen in de stofwisseling die bepalend zijn voor de lokale herstelprocessen. Voorbeelden van deze systemische metabole afwijkingen zijn een tekort aan bijschildklierhormoon of vitamine $D$, of ondervoeding op basis van een tekort aan calorieën of eiwitten. Bij 84 procent van de patiënten met een non-union lijkt een van deze afwijkingen een rol te spelen ${ }^{22}$. Het lijkt mij dus gerechtvaardigd om de pentagoon te vervangen door een hexagoon.

Om deze zesde hoek klinisch te bestuderen zijn met name twee patiëntgroepen interessant. Enerzijds zijn er de multitraumapatiënten die, veelal op jonge leeftijd, ernstige meervoudige verwondingen hebben. Kenmerkend voor deze patiënten is dat zij een forse verstoring in de normale stofwisseling in het gehele lichaam hebben, met onder ander een lage bloeddruk door het bloedverlies, een forse ontstekingsreactie door de kneuzingen, de verscheuring van weefsel en de vaak meerdere fracturen. Zij ontwikkelen niet alleen vaak een non-union, maar het behandelen van deze non-union is ook vaak bijzonder moeizaam. Hier is een analogie te maken naar de slachtoffers van het slagveld die de acute fase hadden overleefd en meervoudig orgaanfalen krijgen: het hele lichaam gaat als het ware in de 'overdrive' om alle schade te herstellen. Deze patiënten hebben in eerste instantie gewoon voldoende herstelcapaciteiten, maar er is in korte tijd een zo grote schade opgetreden dat het compensatiemechanisme in de stofwisseling op

\footnotetext{
${ }^{21}$ The diamond concept-open questions. Giannoudis PV, Einhorn TA, Schmidmaier G, Marsh D. Injury. 2008;39 Suppl 2:S5-8.

22 Metabolic and endocrine abnormalities in patients with nonunions. Brinker MR, O'Connor DP, Monla YT, Earthman TP. J Orthop Trauma. 2007;21(8):55770.
} 
lichaamsniveau tekortschiet. Inmiddels weten we uit eigen onderzoek dat de herstelprocessen in de stofwisseling ter plaatse van het non-unionweefsel zelf verstoord zijn door stoornissen in de stofwisseling op lichaamsniveau van deze patiënten. Een tekort aan specifieke eiwitten is daar een onderdeel van, alhoewel nader onderzoek hiernaar nog nodig is.

Anderzijds is er een tweede groep patiënten, bij wie het risico op een niet goed genezende fractuur verhoogd is, betreft de oudere, kwetsbare patiënten met een eenvoudige val een fractuur oplopen, zoals een breuk van het heupbot. $\mathrm{Bij}$ deze traumapatiënt is het letsel op zich niet zo groot als bij de eerste groep, maar is het herstelvermogen al verminderd vóórdat het letsel optreedt. Ook bij deze patiënten is frequent een verstoring in de stofwisseling waarneembaar, waarbij in dertig tot zestig procent van de patiënten zelfs sprake is van eiwit- en calorieondervoeding ${ }^{23}$. Het risico dat de fractuur van de heup niet geneest is zelfs zo groot dat we liever kiezen voor een gewrichtsvervangende operatie, een prothese, daar waar een botsparende operatie eigenlijk ook een optie zou moeten zijn. Wederom kiezen we dus eigenlijk voor een mechanische oplossing, terwijl verbeteren van de botgenezing een betere zou zijn.

Samenvattend zijn er bepaalde risicogroepen met een hogere kans hebben op een non-union, bij wie sterke aanwijzingen zijn voor een verstoorde stofwisseling als oorzaak, maar waar de behandeling vooral gericht is op biomechanische aspecten, of waar we met beperkte kennis de stofwisseling proberen te verbeteren.

Het onderzoek dat de komende jaren verricht dient te worden, richt zich wat mij betreft dan ook op deze processen van de stofwisseling tijdens fractuurgenezing. Een beter begrip van de onderliggende afwijkingen, een betere detectie van verstoorde fractuurgenezing bij de patiënt, betere behandelingen en gerichtere evaluatie van de behandeleffecten, gebaseerd op deze afwijkingen in de stofwisseling, zullen een revolutie in de behandeling kunnen betekenen. De afgelopen jaren heeft ons basale onderzoek zich gericht op de invloed van verstoringen in de

\footnotetext{
${ }^{23}$ Functional recovery of older people with hip fracture: Does malnutrition make a difference? Li H-JJ, Cheng H-SS, Liang J, Wu C-CC, Shyu Y-ILI. Journal of advanced nursing 2013,69, 1691-1703.
} 
stofwisseling van aminozuren op de fractuurgenezing. Aminozuren zijn de bestanddelen waaruit eiwitten worden gevormd. Deze aminozuren blijken een essentiële rol te spelen in het reguleren van de herstelfase van de fractuurgenezing en geven ons de mogelijkheid tot voedingsinterventies bij traumapatiënten. Samen met de onderzoeksgroep van Bert van Rietbergen aan de Technische Universiteit in Eindhoven verrichten we micro-CT scans om de fractuurgenezing te evalueren. Dit basale onderzoek wordt op muizen verricht met een model dat we samen met de het onderzoeksinstituut van de AO in Davos, Zwitserland hebben ontwikkeld ${ }^{24}$.

Ons onderzoek heeft zich met name gericht op de aminozuren arginine en citrulline en is de afgelopen jaren door Nina Wijnands en Dennis Meesters verricht ${ }^{25}$. Inmiddels hebben we bij de muizen al kunnen aantonen dat voedingssuppletie met een extra dosis van deze aminozuren tot een betere fractuurgenezing leidt.

Nader onderzoek zal het exacte werkingsmechanisme nog moeten ophelderen. Het onderzoek, zoals geleid door Taco Blokhuis, naar het eerdergenoemde fractuurhematoom als belangrijke eerste metabole omgeving voor genezing van de fractuur, zal hier een essentiële bijdrage aan leveren.

Een ander interessant onderdeel in dit basaalwetenschappelijke onderzoek naar de rol van stofwisseling bij de fractuurgenezing is de invloed van de spieren op de fractuurgenezing. Dat de spier als een mechanisch onderdeel werkt om het bot en gewricht te laten bewegen is uiteraard al lang bekend. Ouderen die op de spoedeisende hulp komen met een gebroken heup blijken bij binnenkomst een lagere spiermassa en ook een minder goede spiersamenstelling te hebben dan mensen zonder gebroken heup, zoals onder andere door Irene Fleur Kramer aangetoond ${ }^{26}$. Deze verminderde spiermassa leidt bij de

\footnotetext{
${ }^{24}$ Deficiency of inducible and endothelial nitric oxide synthase results in diminished bone formation and delayed union and nonunion development. Meesters DM, Neubert S, Wijnands KA, Heyer FL, Zeiter S, Ito K, Brink PR, Poeze M. Bone 2016;83:111-8.

${ }^{25}$ Arginase-1 deficiency regulates arginine concentrations and NOS2-mediated NO production during endotoxemia. Wijnands KA, Hoeksema MA, Meesters DM, van den Akker NM, Molin DG, Briedé JJ, Ghosh M, Köhler SE, van Zandvoort MA, de Winther MP, Buurman WA, Lamers WH, Poeze M. PLoS One 2014;9(1): e86135.

${ }^{26}$ Extensive Type II Muscle Fiber Atrophy in Elderly Female Hip Fracture Patients. Kramer IF, Snijders T, Smeets JSJ, Leenders M, van Kranenburg J,
} 
oudere traumapatiënt tot een slechtere revalidatie na het operatieve herstel van de fractuur. Buiten dit mechanische aspect functioneert de spier echter ook als een belangrijke factor in de stofwisseling. Diverse eiwitten die in de spier geproduceerd worden, beïnvloeden het bot ter plaatse van het contactpunt met de spier, het periost. Dit heb ik al eerder als een belangrijke locatie voor de botgenezing beschreven. Vanuit de kliniek is ook bekend dat beschadigingen van dit periost de fractuurgenezing sterk verminderen. Uit ons basale onderzoek blijkt dat beschadiging ervan leidt tot een verlaagde hoeveelheid aminozuren en bovendien gerelateerd is aan een verlaagde hoeveelheid groeifactoren uit de spier die de botgroei moeten stimuleren. Ook hierin kunnen voedingsinterventies mogelijk een rol spelen. Dit zullen we de komende jaren onderzoeken. Ook is het onderzoekswerk van Pascal Hannemann met de elektromagnetische inductie van botgroei $^{27}$ is in deze interessant om vanuit extern een stimulatie van bot en spierregeneratie te geven. Verder zullen we met voedingsstudies de algehele afwijkingen in de stofwisseling proberen te verbeteren om daarmee het herstel van bot en spier te bevorderen. Naast deze voedingsinverventies verwacht ik dat er in de toekomst botgroei-bevorderende stoffen worden ontwikkeld die als coating op platen en pennen worden aangebracht om de metabole processen ook lokaal gunstig te sturen.

Een beter begrip van de stofwisseling zal ook de mogelijkheid geven ook specifieke markers te vinden die een vroege opsporing van afwijkende fractuurgenezing mogelijk maken en tot gerichtere interventies leiden om de fractuurgenezing te bevorderen.

Een belangrijke vraag is hoe dan uiteindelijk te meten of deze interventies ook effectief zijn bij de behandeling van patiënten in de kliniek. In de afgelopen jaren hebben we onderzoek verricht naar effectmetingen, die ik achtereenvolgens van macro naar microniveau zal

den Hoed M, Verdijk LB, Poeze M, van Loon LJC.J Gerontol A Biol Sci Med Sci 2017;72(10):1369-1375.

${ }_{27} \mathrm{CT}$ scan-evaluated outcome of pulsed electromagnetic fields in the treatment of acute scaphoid fractures: a randomised, multicentre, doubleblind, placebo-controlled trial. Hannemann PF, van Wezenbeek MR, Kolkman $\mathrm{KA}$, Twiss EL, Berghmans CH, Dirven PA, Brink PR, Poeze M. Bone Joint J 2014;96-B(8):1070-6. 
bespreken. Het uiteindelijke doel van de behandeling is dat de patiënt weer goed kan functioneren in het dagelijks leven en dat kunnen we de patiënt zelf vragen. Maar om de behandeling gericht op de afwijkende stofwisseling te kunnen sturen, hebben we ook behoefte aan meer objectieve maten, op het niveau van het functioneren van de beschadigde ledematen. Daarom heeft Sander van Hoeve samen met de groep van Kenneth Meijer bij patiënten na een fractuur van de voet en enkel gekeken of de loopgang gerelateerd is aan het al of niet normaal verlopen van de fractuurgenezing ${ }^{28}$. De techniek van de loopganganalyse is gebaseerd op de filmtechniek 'motion capture', waarbij met meerdere camera's de beweging van reflecterende bolletjes op het lichaam, tijdens bewegen omgezet wordt in een computermodel dat een nauwkeurige bewegingsanalyse kan doen. Met deze techniek hebben we gezien dat abnormale loopgang optreedt als de fractuurgenezing niet adequaat is. Ook hierbij is nog veel werk te verrichten om de techniek te ontwikkelen tot een instrument dat het effect van interventies in de kliniek kan meten. Hierin wordt binnen de 'specialty' beweging, een groep wetenschappers van zowel de universitaire groepen als artsen in de patiëntenzorg, intensief samengewerkt. De aanschaf van het nog meer geavanceerde CAREN-systeem om de beweegpatronen te onderzoeken zal ons daarbij veel nieuwe mogelijkheden geven

Verder heeft Frans Heyer samen met de groep van professor Joop van den Bergh met behulp van een extra nauwkeurige, een zogenaamde hoge resolutie CT-scanner het proces van genezing na een polsfractuur bestudeerd. Met behulp van deze techniek kunnen we meten in welke mate en met welke snelheid een fractuur heelt ${ }^{29}$ en wat we op basis daarvan over de uiteindelijke functie kunnen zeggen. Door de zeer nauwkeurige beelden van deze speciale CT-scanner, gemaakt op verschillende momenten tijdens het genezingsproces, over elkaar heen te leggen kan bepaald worden op welke plek er bot aangemaakt en afgebroken

\footnotetext{
${ }^{28}$ Gait Analysis and Functional Outcome After Calcaneal Fracture. van Hoeve S, de Vos J, Verbruggen JP, Willems P, Meijer K, Poeze M. J Bone Joint Surg Am 2015;97(22):1879-88.

${ }^{29}$ Fracture Repair in the Distal Radius in Postmenopausal Women: A FollowUp 2 Years Postfracture Using HRpQCT. de Jong JJ, Heyer FL, Arts JJ, Poeze $M$, Keszei AP, Willems PC, van Rietbergen B, Geusens PP, van den Bergh JP. J Bone Miner Res 2016;31(5):1114-22.
} 
wordt na een fractuur. In de toekomst willen we verder onderzoeken of met deze techniek veranderingen in dit patroon als gevolg van voedingsinterventies kunnen worden opgepikt. Die veranderingen hebben we overigens al kunnen aantonen voor vitamine $\mathrm{D}$.

Op een nog meer gedetailleerd niveau kijken we naar de fractuurgenezing zelf, door daadwerkelijk naar de stofwisseling in het bot te kijken. Al lange tijd wordt in het laboratorium van de Heelkunde en Humane biologie met behulp van niet-radioactief gelabelde markers op de aminozuren, het eiwit- en aminozuurmetabolisme onderzocht. Met een speciale techniek, de massaspectrometrie, kunnen we dan de omzetting van de eiwitten en aminozuren in het bot meten. Dit onderzoek doen we samen me de onderzoeksgroep van professor Ron Heeren. Inmiddels zijn we begonnen met het ontrafelen van de achterliggende mechanismen van de stofwisseling die in de vroege fasen van fractuurgenezing een rol spelen ${ }^{30}$. Daarnaast zijn we samen met Tiffany Porta, vanuit het M4I onderzoeksinstituut, gestart met de vertaling van deze techniek op basis van massa spectrometrie naar een toepassing in de kliniek. Met behulp van een laserstraal worden minuscule gaatjes in het bot rondom een fractuur gemaakt, de daarbij vrijkomende producten worden geanalyseerd om tijdens een operatie een indruk te krijgen van de levensvatbaarheid en het groeipotentieel van de fractuurdelen. Dit geeft niet alleen beter inzicht in het stofwisselingsprocessen van een non-union bij patiënten, maar ook de mogelijkheid om de afwijkende botgenezing vroegtijdig op te sporen en behandelingen te evalueren. Uiteindelijk moeten we de bevindingen van al dit onderzoek per slot van rekening ten goede laten komen aan de patiëntenzorg.

Naast de beschreven uitdagingen op het gebied van onderzoek, organisatie en opleiding is er nog een belangrijk aspect wat aandacht behoeft. Misschien is het $u$ opgevallen dat in de titel een teken staat voor een trademark, een handelsmerk. We hebben namelijk te maken met een imagoprobleem. Het gezondheidszorgvraagstuk trauma

\footnotetext{
${ }^{30}$ Imaging and mapping of mouse bone using MALDI-imaging mass spectrometry. Fujino Y, Minamizaki T, Yoshioka H, Okada M, Yoshiko Y. Bone Rep 2016;5:280-285.
} 
wordt wel gezien als een onzichtbaar probleem: ondanks de enorme aantallen staan ongevalsslachtoffers pas in de belangstelling van onze samenleving als de aantallen die in één keer vallen groot genoeg zijn of het een opzienbarend incident betreft. Ik noem de Bijlmerramp of meer recent de slachtoffers bij het ongeval met de monstertruck in Haaksbergen. Elke maand vallen er in het Nederlandse verkeer net zoveel doden plus acht keer zoveel ernstige slachtoffers als bij deze twee welbekende ongevallen samen. Dat is een droevige statistiek die we ons niet voldoende realiseren en een die vraagt om een gezamenlijke inspanning om dit op het netvlies van ons allemaal te krijgen; beleidsmakers, ziekenhuisbestuurders en de bevolking in het algemeen. In de VS hebben onze collega's dat inmiddels gesignaleerd voor de slachtoffers van schotwonden. De hoofdredacteuren van vier medische toptijdschriften hebben recent samen aandacht gevraagd voor het volksgezondheidsprobleem ten gevolge van schietincidenten. $\mathrm{Zij}$ trekken de vergelijking met infectieziekten. Een vergelijkbaar aantal slachtoffers door een uitbraak van een infectieziekte zou volstrekt onacceptabel gevonden worden en daarmee zouden enorm veel menskracht en middelen ingezet gaan worden. In Nederland blijft het aantal schot- en steekwonden, met $5 \%$ van het totale aantal letsels, gelukkig beperkt, maar voor verkeersslachtoffers gaat eenzelfde vergelijking op. Bij de dagelijks optredende aantallen verkeersslachtoffers heeft het weinig zin om ons te verschuilen achter de schuldvraag. Bedenk hierbij dat het vaak om jonge slachtoffers gaat. Zij hebben, als zij een ongeval overleven, vaak langdurig of zelfs levenslang beperkingen bij hun participatie in de maatschappij, met onder andere langdurig ziekteverzuim. Hierin ligt letterlijk en figuurlijk de marktwaarde van het beperken van de gevolgen van trauma's. Bij de grote toename van oudere patiënten die vallen en iets breken is het niet voldoende om te constateren dat deze problemen niet zo mediageniek zijn als hart en vaatziekten of kanker worden gezien; de heup is immers niet hip. Niet alleen is de sterfte van deze patiënten hoog, vaak kunnen deze patiënten na hun fractuur niet meer zelfstandig wonen of worden ze bedlegerig of rolstoelafhankelijk. Patiënt en zorgverlener worden dagelijks geconfronteerd met de beperkte mogelijkheden voor herstel, hulp en mantelzorg. 
Om het 'merk' trauma te promoten is een aantal zaken van belang. Beter begrip van de herstelmogelijkheden van het bot en de spier zal ons helpen de patiënten te helpen herstellen. Wat mij betreft is het oprichten van een ongevalsfonds, bijvoorbeeld binnen de Health Care Foundation Limburg de hoogste tijd. Zo'n ongevalsfonds zal het traumaonderzoek in onze regio een flinke boost geven. Het op te richten landelijk onderzoeksconsortium, dat ook door de Nederlandse Vereniging voor Traumachirurgie wordt omarmd, zal sturing geven aan de te onderzoeken vraagstellingen.

Recent is de naamgeving van ons vak veranderd van Traumatologie naar Traumachirurgie om het chirurgische aspect in ons vak meer te benadrukken. Dat ik hier in feite voor u mag staan als de eerste hoogleraar Traumachirurgie is dan ook een hele eer. Het lijkt mij dat hier voor een aantal andere universiteiten nog een uitdaging ligt. Het niet aan willen of kunnen stellen van een hoogleraar Traumachirurgie in een aantal andere academische ziekenhuizen baart mij zorgen. Ik denk dat de omvang van de problematiek, zoals ik $u$ geschetst heb, de instelling van een hoogleraar Traumachirurgie in al deze plaatsen rechtvaardigt, zodat zij het belang van ons vak ook in ieder academisch ziekenhuis kan benadrukken en een promotor in de figuurlijke zin van het woord kan zijn voor het onderzoek in de Traumachirurgie.

Ter afsluiting wil ik stellen dat, of het nu de regionale of landelijke traumazorg betreft, de opleiding tot basisarts en traumachirurg of het onderzoek naar het herstel van bot en spier na een trauma, we aan de vooravond staan van aanzienlijke veranderingen in de traumachirurgie staan: de verandering in de traumazorg gericht op lange termijneffecten en gevolgen van het letsel, de verandering van de opleiding tot traumachirurg als zelfstandige entiteit en de verandering van het traumaonderzoek van biomechanisch naar metabool. In die zin is er sprake van een revolutie. Interessant genoeg zullen veel van deze veranderingen echter niet plotseling optreden, maar zich ontrollen. Het woord evolutie komt van 'evolvere', dat zich laat vertalen als 'zich ontrollen'. De grote veranderingen in de traumazorg, het onderwijs en de onderzoeksaspecten van de traumachirurgie zullen geleidelijk leiden tot een betere 
kwaliteit. De voorgestelde doelen binnen de traumachirurgie zijn dus niet òfwel een revolutie òf een evolutie, maar gelijktijdig zowel een revolutie als een evolutie.

Ik heb gezegd. 

